\title{
Late Effects of Allogeneic Hematopoietic Stem Cell Transplantation in an Asian Patient Population
}

\author{
Chong Mui Fong, Lim Yan Jiun, Ng Hong Yen
}

Department of Pharmacy, Singapore General Hospital, Singapore

\begin{abstract}
Background: Long-term survivors of allogeneic hematopoietic stem cell transplantation (alloHSCT) are at a substantial risk of developing medical late effects. We aimed to determine the incidence of metabolic syndrome (MS), cardiovascular (CV) events, bone density loss, and fractures in a cohort of patients who underwent alIOHSCT for hematologic disorders. The potential risk factors for MS, CV events, bone density loss, and fractures, as well as the sufficiency of existing monitoring measures in our institution, were also evaluated.

Methods: A single-center, retrospective study was conducted. We included patients who underwent alloHSCT at the Singapore General Hospital between January 2011 and December 2016, were at least 21 years old, and had a minimum follow-up period of 6 months. Patients with MS-related data comprised the CV study population, whereas patients with bone loss-related data comprised the skeletal study population. Associations between risk factors and the development of MS or bone loss were assessed using a univariate analysis followed by multivariate logistic regression. All analyses were performed using SPSS version 23.

Results: A total of 91 patients were included in the CV study population, of which $13(14.3 \%)$ had preexisting MS, $17(18.7 \%)$ developed MS, and 5 (5.5\%) developed CV events after alloHSCT. Thirty-one patients were included in the skeletal study population, of which $2(6.5 \%)$ had preexisting bone loss, $23(71.0 \%)$ developed osteopenia or osteoporosis, and $2(6.5 \%)$ had a fracture. After adjusting for preexisting MS, pretransplant abdominal obesity $(p=0.002)$, elevated triglyceride $(p<0.001)$, and fasting hyperglycemia $(p<0.001)$ significantly predicted MS on multivariate analyses. Only female sex predicted the risk of bone loss after alloHSCT on multivariate analyses after adjusting for preexisting osteopenia $(p=0.02)$. Of the 174 patients who underwent alloHSCT during the study period, $83(47.7 \%)$ and $143(82.2 \%)$ patients had no MS-related data and bone loss-related data, respectively.

Conclusion: Long-term alloHSCT survivors are at an increased risk of MS, CV complications, and bone loss. This underscores the importance of close monitoring and timely interventions to reduce long-term morbidity and mortality.
\end{abstract}

Key words long-term effects, allogeneic stem cell transplantation, long-term follow-up

Submitted December 19, 2020; Accepted May 5, 2021; Published online August 25, 2021; Issued online August 25, 2021

Correspondence: Chong Mui Fong, Department of Pharmacy, Singapore General Hospital, Outram Road, Block 7 Level 2 Hematology Pharmacy, Singapore 169608, E-mail: chong.mui.fong@sgh.com.sg

\section{Introduction}

Hematopoietic stem cell transplantation (HSCT) is being increasingly used as a potentially curative treatment modality for many high-risk leukemias and nonmalignant conditions. However, long-term survivors are at a substantial risk of developing medical late effects ${ }^{1-4}$ and face higher mortality rates than the general popula$\operatorname{tion}^{5-7}$. In the Bone Marrow Transplant Survivor Study published in 2007, cardiac complications were found to contribute to $3 \%$ of premature deaths in bone marrow transplant recipients, and this was increased 2.3-fold compared with the general population ${ }^{6}$.

The development of metabolic syndrome (MS) after transplantation is an increasing concern among allogeneic HSCT (alloHSCT) survivors. The prevalence of MS reported in earlier studies conducted among patients from American and European centers ranged from 
$31-49 \%{ }^{8-12}$. In addition to risk factors common to the general population, such as genetic predisposition, age, and lifestyle factors ${ }^{13}$, alloHSCT recipients are likely to be more susceptible to MS than the general population for various reasons. These include damage to the neurohormonal system and vascular endothelium from pretransplant conditioning regimen as well as the immunological effects of allografting and development and treatment of graft-versus-host disease (GVHD) ${ }^{9}$. A follow-up study of 23 alloHSCT survivors reported hyperinsulinemia, impaired glucose tolerance, hypertriglyceridemia, low high-density lipoprotein cholesterol (HDL-C) levels, and abdominal obesity to be more common among the alloHSCT survivors as compared with a group of leukemia patients who did not undergo alloHSCT or healthy controls ${ }^{14}$.

It has been shown that individuals in the general population with MS are at increased lifetime risk of developing cardiovascular $(\mathrm{CV})$ diseases ${ }^{15}$. As alloHSCT survivors may be at risk of $\mathrm{CV}$ diseases secondary to cardiotoxic chemotherapy or radiotherapy ${ }^{16-18}$, the presence of MS may increase this risk.

Bone density loss after transplantation is another factor that affects the quality of life of alloHSCT survivors ${ }^{19}$. Resultant fractures result in chronic pain, longterm disability, and premature death ${ }^{20}$. Osteoporosis and osteopenia occur in approximately $32 \%$ and $50 \%$ of cases, respectively within 6-12 months after alloHSCT ${ }^{13,19,21-23}$. In addition to risk factors common to the general population, alloHSCT-associated risk factors include increased corticosteroid exposure, gonadal insufficiency, and the use of total body irradiation (TBI) as part of conditioning ${ }^{24,25}$.

Recommended screening and preventive strategies for HSCT survivors have been made collectively by transplant experts from the European Group for Blood and Marrow Transplantation, Center for International Blood and Marrow Transplant Research, and American Society of Blood and Marrow Transplantation ${ }^{13,25,26}$. However, the applicability of these guidelines in the Asian population is yet to be established. Appropriate populationspecific adaptations of these guidelines are required to facilitate the development of screening guidelines and interventions to mitigate CV- and skeletal-related morbidity and mortality among survivors of alloHSCT in the Asian population.

This study aimed to characterize the incidence of MS, CV events, and bone loss in an Asian population who underwent alloHSCT and the factors that predispose them to these long-term complications.

The primary objective of this study was to determine the incidence of MS, CV events, bone density loss, and fractures in a cohort of patients who underwent alloHSCT for hematologic disorders. The secondary ob- jectives were (1) to evaluate the potential association between patient as well as transplant factors and development of MS, CV events, bone density loss, and fractures and (2) to evaluate the sufficiency of existing long-term monitoring strategies.

\section{Materials and Methods}

\section{Patients and data management}

At the point that this study was conducted, there were no institutional guidelines in place to guide posttransplant follow-up. Primary transplant physicians followed up with patients at regular intervals, and any posttransplant investigations and vaccinations were performed at the discretion of each physician.

Patients aged $\geq 21$ years who underwent alloHSCT at Singapore General Hospital between January 2011 and December 2016, with a minimum follow-up period of 6 months, were included in this study. Patients who did not have MS- or bone density loss-related data or had incomplete follow-up were excluded.

A single-center retrospective review was carried out. Patient, transplant, and MS- and bone loss-related variables were collected via review of inpatient and outpatient medical records as well as electronic medication records. All data collected were recorded in a data collection form approved by the Central Institutional Review Board. Informed consent was waived due to the retrospective nature of this study.

\section{Definitions}

In this study, MS was defined according to the 2009 International Diabetes Federation and American Heart Association/National Heart, Lung, and Blood Institute criteria $^{27}$, by the presence of three or more of its core clinical measures: abdominal obesity, elevated triglyceride (TG) level, reduced HDL-C level, or elevated blood pressure or serum glucose level, as shown in Table A1 (Appendix). The Asian criteria for abdominal obesity with waist circumference cutoffs of $\geq 90 \mathrm{~cm}$ for men and $\geq 80 \mathrm{~cm}$ for women were used ${ }^{15}$. A body mass index (BMI) of $\geq 27.5 \mathrm{~kg} / \mathrm{m}^{2}$ was used as a substitute for abdominal obesity if waist circumference was not available ${ }^{28}$.

Bone mineral density (BMD) results are expressed as the number of standard deviations from normal values of young, healthy, sex-matched controls (T-score) and from the normal values of age- and sex-matched controls (Z-score). The T-score is generally used to determine BMD in postmenopausal women and men aged $\geq 50$ years. For young adults and men up to the age of 49 years, Z-scores are preferred to prevent overestimation of age association of $\mathrm{BMD}^{21,23,29}$. Patients were classified according to the World Health Organization defi- 
Table 1. Patient and transplant characteristics by MS status

\begin{tabular}{|c|c|c|c|c|c|c|c|c|c|}
\hline \multirow{2}{*}{ Characteristic } & \multicolumn{2}{|c|}{ All patients $(n=95)$} & \multicolumn{2}{|c|}{ No MS (n=61) } & \multicolumn{2}{|c|}{ MS $(n=17)$} & \multicolumn{2}{|c|}{$\begin{array}{l}\text { Pre-existing } \\
\text { MS }(n=13) /\end{array}$} & \multirow{2}{*}{$p$-value } \\
\hline & $\begin{array}{l}\mathrm{N} \text { or } \\
\text { Median }\end{array}$ & $\begin{array}{l}\text { Percent } \\
\text { or Range }\end{array}$ & $n$ & $\begin{array}{l}\text { Percent } \\
\text { or Range }\end{array}$ & $\mathrm{n}$ & $\begin{array}{l}\text { Percent } \\
\text { or Range }\end{array}$ & $\mathrm{n}$ & $\begin{array}{l}\text { Percent } \\
\text { or Range }\end{array}$ & \\
\hline Age, yr & 50 & $21-68$ & 48 & $21-66$ & 51 & $27-67$ & 59 & $38-68$ & 0.003 \\
\hline $\begin{array}{l}\text { Race } \\
\text { Chinese } \\
\text { Malay } \\
\text { Others }\end{array}$ & $\begin{array}{r}73 \\
7 \\
15\end{array}$ & $\begin{array}{r}76.8 \% \\
7.4 \% \\
15.8 \%\end{array}$ & $\begin{array}{r}47 \\
6 \\
8\end{array}$ & $\begin{array}{r}77.0 \% \\
9.8 \% \\
13.1 \%\end{array}$ & $\begin{array}{r}13 \\
0 \\
4\end{array}$ & $\begin{array}{r}76.5 \% \\
0 \% \\
23.5 \%\end{array}$ & $\begin{array}{l}9 \\
1 \\
3\end{array}$ & $\begin{array}{r}69.2 \% \\
7.7 \% \\
23.1 \%\end{array}$ & 0.300 \\
\hline Male gender & 41 & $43.2 \%$ & 27 & $44.3 \%$ & 6 & $35.3 \%$ & 8 & $61.5 \%$ & 0.351 \\
\hline $\begin{array}{l}\text { Primary disease } \\
\text { Acute leukemia } \\
\text { Myelodysplastic syndrome } \\
\text { Chronic leukemia } \\
\text { Lymphoma } \\
\text { Others }\end{array}$ & $\begin{array}{r}64 \\
14 \\
5 \\
6 \\
6\end{array}$ & $\begin{array}{r}67.4 \% \\
14.7 \% \\
5.3 \% \\
6.3 \% \\
6.3 \%\end{array}$ & $\begin{array}{r}40 \\
9 \\
4 \\
4 \\
4\end{array}$ & $\begin{array}{r}65.5 \% \\
14.7 \% \\
6.6 \% \\
6.6 \% \\
6.6 \%\end{array}$ & $\begin{array}{l}9 \\
5 \\
1 \\
1 \\
1\end{array}$ & $\begin{array}{r}53.0 \% \\
29.4 \% \\
5.9 \% \\
5.9 \% \\
5.9 \%\end{array}$ & $\begin{array}{r}12 \\
0 \\
0 \\
1 \\
0\end{array}$ & $\begin{array}{r}92.3 \% \\
0 \% \\
0 \% \\
7.7 \% \\
0 \%\end{array}$ & 0.543 \\
\hline$>1 \mathrm{HSCT}$ & 4 & $4.2 \%$ & 3 & $4.9 \%$ & 1 & $5.9 \%$ & 0 & $0 \%$ & 1.00 \\
\hline $\begin{array}{l}\text { Stem cell source } \\
\text { Peripheral blood stem cells } \\
\text { Bone marrow } \\
\text { Cord blood }\end{array}$ & $\begin{array}{r}84 \\
5 \\
6\end{array}$ & $\begin{array}{r}88.4 \% \\
5.3 \% \\
6.3 \%\end{array}$ & $\begin{array}{r}51 \\
4 \\
6\end{array}$ & $\begin{array}{r}83.6 \% \\
6.6 \% \\
9.8 \%\end{array}$ & $\begin{array}{r}16 \\
1 \\
0\end{array}$ & $\begin{array}{r}94.1 \% \\
5.9 \% \\
0 \%\end{array}$ & $\begin{array}{r}13 \\
0 \\
0\end{array}$ & $\begin{array}{r}100 \% \\
0 \% \\
0 \%\end{array}$ & 0.595 \\
\hline $\begin{array}{l}\text { Conditioning regimen } \\
\text { Myeloablative } \\
\text { Non-myeloablative / Reduced intensity } \\
\text { Use of TBI }\end{array}$ & $\begin{array}{l}29 \\
66 \\
30\end{array}$ & $\begin{array}{l}30.5 \% \\
69.5 \% \\
31.6 \%\end{array}$ & $\begin{array}{l}23 \\
38 \\
23\end{array}$ & $\begin{array}{l}37.7 \% \\
62.3 \% \\
37.7 \%\end{array}$ & $\begin{array}{r}3 \\
14 \\
4\end{array}$ & $\begin{array}{l}17.6 \% \\
82.4 \% \\
23.5 \%\end{array}$ & $\begin{array}{r}1 \\
12 \\
2\end{array}$ & $\begin{array}{r}7.7 \% \\
92.3 \% \\
15.4 \%\end{array}$ & $\begin{array}{l}0.378 \\
0.238\end{array}$ \\
\hline $\begin{array}{l}\text { Immunosuppressant tapering } \\
\text { Time to immunosuppression tapering, days }\end{array}$ & 99 & $28-663$ & 97 & $28-663$ & 103 & $48-429$ & 90 & $28-255$ & 0.452 \\
\hline aGVHD Diagnosis & 56 & $58.9 \%$ & 37 & $60.7 \%$ & 10 & $58.8 \%$ & 6 & $46.2 \%$ & 0.628 \\
\hline $\begin{array}{l}\text { aGVHD Treatment } \\
\text { Budesonide and other topical steroids } \\
\text { Systemic steroids }\end{array}$ & $\begin{array}{l}40 \\
34\end{array}$ & $\begin{array}{l}42.1 \% \\
35.8 \%\end{array}$ & $\begin{array}{l}28 \\
20\end{array}$ & $\begin{array}{l}45.9 \% \\
32.8 \%\end{array}$ & $\begin{array}{l}8 \\
7\end{array}$ & $\begin{array}{l}47.1 \% \\
41.2 \%\end{array}$ & $\begin{array}{l}3 \\
4\end{array}$ & $\begin{array}{l}23.1 \% \\
30.8 \%\end{array}$ & $\begin{array}{l}0.297 \\
0.796\end{array}$ \\
\hline cGVHD Diagnosis & 40 & $42.1 \%$ & 28 & $45.9 \%$ & 6 & $35.3 \%$ & 4 & $30.8 \%$ & 0.505 \\
\hline $\begin{array}{l}\text { cGVHD Treatment } \\
\text { Systemic steroids }\end{array}$ & 33 & $34.7 \%$ & 23 & $37.7 \%$ & 5 & $29.4 \%$ & 3 & $23.1 \%$ & 0.605 \\
\hline Total time on systemic steroids, days & 84 & $0-2,061$ & 84 & $0-1,555$ & 106 & $0-1,322$ & 34 & $0-2,061$ & 0.839 \\
\hline
\end{tabular}

MS, metabolic syndrome; HSCT, hematopoietic stem cell transplantation; TBI, total body irradiation; aGVHD, acute graft-versus-host disease; cGVHD, chronic graft-versus-host disease

nition $^{29}$. Normal BMD was defined as a T-score $\geq-1$ $\mathrm{SD}$, osteopenia was defined as a T-score $<-1.0$ and $>$ -2.5 , and osteoporosis was defined as a T-score $\leq-2.5$. Z-scores between -1 and -2 were used to define osteopenia, while Z-scores $\leq-2$ were defined as osteoporosis in young adults ${ }^{22}$.

$\mathrm{CV}$ events included cerebrovascular diseases such as stroke, transient ischemic attack, cerebral arterial occlusion, and symptomatic lacunar infarcts and coronary heart diseases (CHD) such as angina pectoris, myocardial infarction, chronic CHD, and peripheral arterial disease (PAD), which include claudication, rest pain, acute ischemia, and gangrene ${ }^{18,30}$.

\section{Statistical analysis}

Descriptive statistics were used to summarize the patients' baseline demographics. To compare baseline characteristics between groups, Pearson's chi-square or Fisher's exact test was used for categorical variables, and the Kruskal-Wallis test was used for continuous variables. To study the risk factors associated with the development of MS, patients with preexisting MS and those who developed MS after alloHSCT were grouped together and compared with patients who did not develop MS. This was also performed to investigate the risk factors associated with skeletal events.

Patient and transplant factors that were potentially associated with MS, CV events, and bone loss were assessed using a univariate analysis followed by multivariate logistic regression. Univariate analysis was performed using Pearson's chi-square test for categorical variables and the Mann-Whitney $U$ test for continuous variables. Factors that were found to be clinically and statistically significant $(\mathrm{p}<0.05)$ during univariate analysis were included in the multivariate analysis. All analyses were performed using SPSS version 23 (Armonk, NY: IBM Corp). 
Table 2. Screening recommendations according to current guidelines and screening rates in our study

\begin{tabular}{|c|c|c|c|}
\hline Organ System & Clinical Measure & $\begin{array}{l}\text { Screening recommendations as per current guidelines } \\
(13,25,26)\end{array}$ & This study* \\
\hline \multirow{4}{*}{$\begin{array}{l}\text { Cardiac and } \\
\text { vascular }\end{array}$} & $\begin{array}{l}\text { Weight, height } \\
\text { and BMI }\end{array}$ & $\begin{array}{l}\text { - Weight, height and BMI assessment at every clinic visit } \\
\text { (at least yearly) } \\
\text { - Waist circumference measurement yearly } \\
\text { - Consider dual energy X-ray absorptiometry (DXA) to } \\
\text { assess sarcopenia }\end{array}$ & $\begin{array}{l}-100 \% \text { height and weight at least } 6 \\
\text { months post HSCT } \\
\text { - Frequency not measured } \\
\text { - } 0 \% \text { waist circumference } \\
\text { - 0\% DXA }\end{array}$ \\
\hline & Dyslipidemia & $\begin{array}{l}\text { - Initial lipid profile } 3 \text { months after HSCT } \\
\text { - High-risk patients (on CNIs and corticosteroids), repeat } \\
\text { every } 3-6 \text { months } \\
\text { - Standard risk patients, lipid profile every } 5 \text { yrs in males } \\
\geq 35 \text { yo and females } \geq 45 \text { yo } \\
\text { - Shorter intervals for lipid levels close to that warranting } \\
\text { therapy }\end{array}$ & $\begin{array}{l}\text { - Average number of lipid panel done per } \\
\text { patient }=2.8 \\
\text { - Median follow up of } 3.6 \text { years }(0.53 \\
-41.3) \\
\text { - Time to first lipid panel not measured } \\
\text { - Frequency not measured }\end{array}$ \\
\hline & Blood pressure & $\begin{array}{l}\text { - Blood pressure assessment at every clinic visit (at least } \\
\text { yearly) }\end{array}$ & $\begin{array}{l}-100 \% \\
\text { - Measured at each clinic visit } \\
\text { - Max } 1 \text { year interval between clinic visits }\end{array}$ \\
\hline & Hyperglycemia & $\begin{array}{l}\text { - High-risk patients with ongoing risk factors (on system- } \\
\text { ic corticosteroids), HbA1C or fasting plasma glucose } \\
\text { (FPG) } 3 \text { months after HSCT, repeat every } 3-6 \text { months } \\
\text { - Standard risk adult patients, screening every } 3 \text { years in } \\
\text { adults } \geq 45 \text { years or in those with sustained higher } \\
\text { blood pressure }(>135 / 80 \mathrm{mmHg} \text { ) }\end{array}$ & $\begin{array}{l}\text { - } 100 \% \text { FPG at least } 6 \text { months post } \\
\text { HSCT } \\
\text { - Frequency not measured } \\
\text { - Time to first FPG not measured } \\
\text { - HbA1c not measured }\end{array}$ \\
\hline \multirow[t]{2}{*}{ Skeletal } & $\begin{array}{l}\text { Bone Mineral } \\
\text { Density (BMD) }\end{array}$ & $\begin{array}{l}\text { - Dual-photon densitometry (largely superseded by DXA) } \\
\text { at } 1 \text { year for all alloHSCT recipients } \\
\text { - Subsequent testing determined by defects or to assess } \\
\text { response to therapy }\end{array}$ & $\begin{array}{l}\text { - Average number of BMD studies done } \\
\text { per patient }=0.38 \\
\text { - Median follow up of } 4.8 \text { years ( } 1.4 \text { - } \\
6.7)\end{array}$ \\
\hline & $\begin{array}{l}\text { Calcium / } \\
\text { Vitamin D levels }\end{array}$ & $\begin{array}{l}\text { - No recommendations } \\
\text { - Physical activity, vitamin D and calcium supplementa- } \\
\text { tion recommended to prevent loss of bone density }\end{array}$ & $\begin{array}{l}-100 \% \text { baseline calcium level and } 3 \\
(9.7 \%) \text { baseline vitamin D level } \\
\text { checked }\end{array}$ \\
\hline
\end{tabular}

${ }^{*} \mathrm{~N}=91$ in $\mathrm{CV}$ study population; $\mathrm{N}=31$ in skeletal study population

$\mathrm{BMI}$, body mass index; HSCT, hematopoietic stem cell transplantation; CNIs, calcineurin inhibitors; FPG, fasting plasma glucose; HbA1c, glycated hemoglobin; DEXA, dual-energy x-ray absorptiometry

\section{Results}

\section{Patient and transplant characteristics}

A total of 174 patients met the inclusion criteria. However, 79 patients that did not have both MS- and bone loss-related data and were excluded. Of the remaining 95 patients included, four did not have any MS-related data, and 64 did not have any bone lossrelated data. Hence, 91 patients comprised the CV study population, and 31 patients comprised the skeletal study population. The patient and transplant characteristics are summarized in Table 1.

The median age of the study population was 50 (range, 21-68) years, and $41(43.2 \%)$ of them were men. Seventy-three patients $(76.8 \%)$ were Chinese, and the majority $(67.4 \%)$ received alloHSCT for acute leukemia. Twenty-nine patients $(30.5 \%)$ received myeloablative conditioning, and 30 patients $(31.6 \%)$ received a conditioning regimen that included the use of TBI.

The median age of the 31 patients included in the skeletal study population was 48 (range, 27-68) years. The median BMI was 21.5 (range, 16.2-34.2) $\mathrm{kg} / \mathrm{m}^{2}$. Four patients (12.9\%) were men, and the majority were Chinese $(77.4 \%)$. There were no differences between the groups at baseline when categorized according to bone loss status.

When patients were categorized based on no development of MS, MS developed after HSCT and preexisting MS, only age was significantly different between the three groups. Patients with preexisting MS and those who developed MS after alloHSCT were older than those who did not develop MS (median age, 59, 51, and 48 years, respectively; $\mathrm{p}=0.005$ ). The use of TBI as part of conditioning and diagnoses of acute and chronic GVHD were not different between the groups. Table 2 illustrates the frequency of screening for each clinical measure in the study population, as compared with currently published recommendations ${ }^{13,25,26}$.

\section{Incidence of MS and CV events in the CV study population}

Of the 91 patients, $17(18.7 \%)$ developed MS after alloHSCT. Together with the 13 patients $(14.3 \%)$ with preexisting MS, the prevalence of MS was $33 \%$, with a median follow-up of 3.6 (range, 0.53-41.3) years. The median time to diagnosis of MS was 356 (range, 441,792) days after alloHSCT. Five patients $(5.5 \%)$ developed CV events, all of whom had CHD. Four of the $\mathrm{CV}$ events occurred in patients without MS, and one occurred in a patient with preexisting MS (Figure 1). 


\section{Incidence of bone loss and fractures in the skele- tal study population}

Of the 31 patients in the skeletal study population, $12(38.7 \%)$ developed osteopenia after alloHSCT, and $11(35.5 \%)$ developed osteoporosis, with a median follow-up of 4.8 (range, 1.4-6.7) years. Two patients $(6.5 \%)$ had preexisting osteopenia, one of whom developed osteoporosis after alloHSCT but did not suffer any fractures. The total prevalence of bone loss in the study population was $80.7 \%$. Two patients $(6.5 \%)$ developed fractures after transplantation. Both fractures were nonvertebral fractures. One of the patients who suffered a fracture had preexisting osteopenia, while the other developed osteoporosis after alloHSCT. The results are summarized in Figure 2. Only $13(41.9 \%)$ patients in the skeletal study population received calcium and vitamin D supplementation after alloHSCT. Only one patient who received supplementation had a fracture.

\section{Risk factors for MS}

Table 3 summarizes the risk factors associated with MS from the univariate and multivariate analyses. From the univariate analysis, the risk factors identified in-

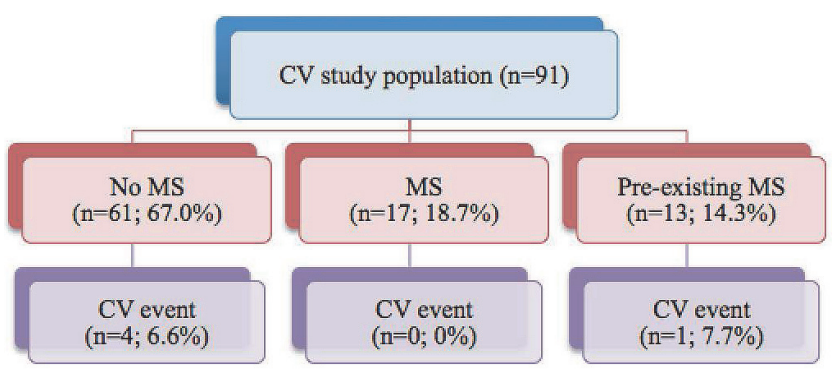

Figure 1. Incidence of MS and CV events CV event in groups with No MS, MS and preexisting MS $\mathrm{CV}$, cardiovascular; MS, metabolic syndrome cluded old age $(\mathrm{p}=0.003)$, baseline abdominal obesity (Odds Ratio [OR], 25.7; 95\% Confidence Interval [CI], 3.1-215.3), elevated TG level (OR, 9.2; 95\% CI, 3.027.7), reduced HDL-C level (OR, 3.9; 95\% CI, 1.410.7), hypertension (HTN) (OR, 12.0; 95\% CI, 4.036.4 ), and fasting hyperglycemia (OR, 22.6; 95\% CI, 14.6-110.0). However, the factors that remained significant from the multivariate analysis, adjusted for preexisting MS, were baseline abdominal obesity (OR, 45.5; 95\% CI, 4.0-500), elevated TG level (OR, 16.4; 95\% CI, 3.8-71.4), and fasting hyperglycemia (OR, 43.5; 95\% CI, 6.8-250). Other factors such as calcineurin inhibitor use, corticosteroid use, use of TBI in conditioning, time to immunosuppressant tapering, and GVHD status were not significantly different between the groups. Risk factors for CV events have not been studied because of the low incidence rate.

\section{MS and related clinical measures}

Analyzing the three groups separately, it was observed that, in addition to reduced HDL-C level, the incidence of each pretransplant clinical measure meeting the criteria for MS was highest among patients with preexisting MS and lowest in patients who did not develop MS. In addition, regardless of MS status, the incidences of abdominal obesity, elevated TG level, reduced HDL-C level, HTN, and elevated fasting glucose levels were higher after transplantation in all three groups. Of the five clinical measures of MS, dyslipidemia after alloHSCT was the most common. A total of $62(68.1 \%)$ patients had elevated TG levels, and 48 (52.7\%) had reduced HDL-C levels after alloHSCT. The results are summarized in Table 4.

\section{Risk factors for bone loss}

Risk factors associated with bone loss from the uni-

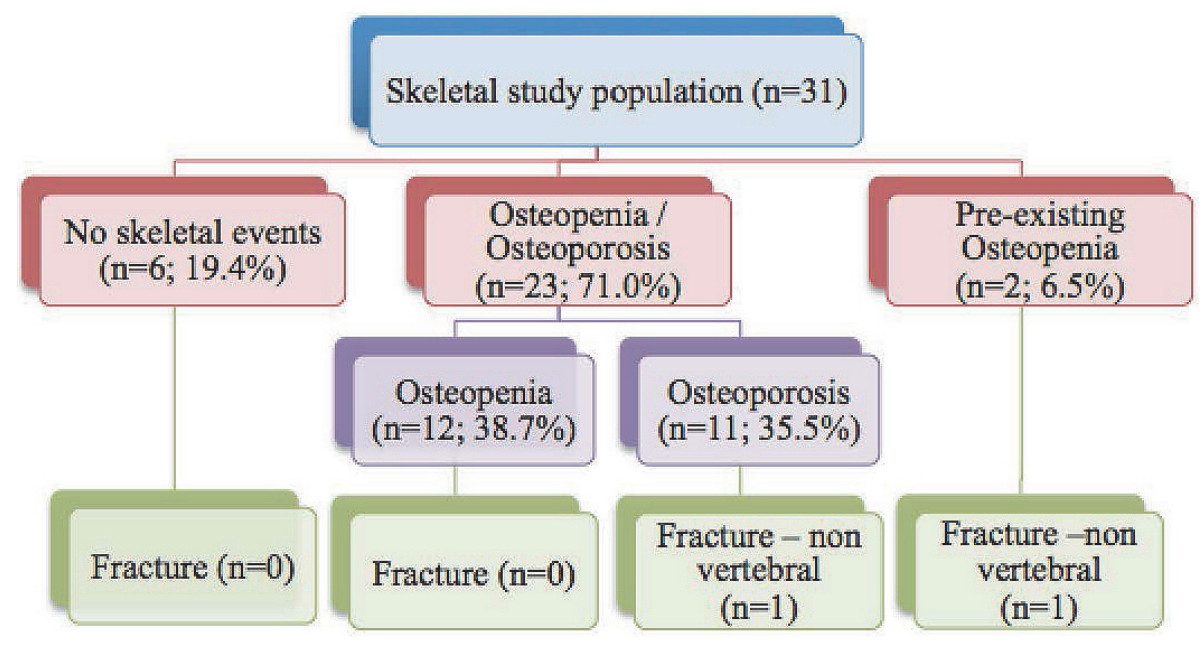

Figure 2. Incidence of bone loss and fractures

Fracture in groups with no bone loss, bone loss and preexisting bone loss 
Table 3. Univariate and multivariate analysis for risk factors predictive of $\mathrm{MS}(\mathrm{N}=91)$

\begin{tabular}{lcrcr}
\hline \multirow{2}{*}{ Variables } & \multicolumn{2}{c}{ Univariate Analysis } & \multicolumn{2}{c}{ Multivariate Analysis } \\
\cline { 2 - 5 } & OR $(95 \% \mathrm{Cl})$ & $p$-value & OR $(95 \% \mathrm{Cl})$ & $p$-value \\
\hline Age & $\mathrm{NA}$ & 0.003 & $\mathrm{NA}$ & $\mathrm{NA}$ \\
Abdominal obesity & $25.7(3.1-215.3)$ & $<0.001$ & $45.5(4.0-500.0)$ & 0.002 \\
Elevated triglycerides & $9.2(3.0-27.7)$ & $<0.001$ & $16.4(3.8-71.4)$ & $<0.001$ \\
Reduced HDL-C & $3.9(1.4-10.7)$ & 0.007 & $\mathrm{NA}$ & $\mathrm{NA}$ \\
\hline Hypertension & $12.0(4.0-36.4)$ & $<0.001$ & $\mathrm{NA}$ & $\mathrm{NA}$ \\
Fasting hyperglycemia & $22.6(14.6-110.0)$ & $<0.001$ & $43.5(6.8-250.0)$ & $<0.001$ \\
\hline
\end{tabular}

MS, metabolic syndrome; HDL-C, high-density lipoprotein cholesterol

Table 4. Incidences of clinical measures of MS by MS status

\begin{tabular}{|c|c|c|c|c|c|c|c|c|}
\hline n (\%) & Pre $(A)^{*}$ & Post (A) & Pre $(B)^{\star}$ & Post (B) & Pre $(C)^{\star}$ & Post (C) & Pre (Total) & Post (Total) \\
\hline Abdominal Obesity & $1(1.6)$ & $5(8.2)$ & $4(23.5)$ & $6(35.3)$ & $5(38.5)$ & $8(61.5)$ & $10(11.0)$ & 19 (20.9) \\
\hline Elevated TG & $6(9.8)$ & $35(57.4)$ & $6(35.3)$ & $15(88.2)$ & 9 (69.2) & 12 (92.3) & $21(23.1)$ & $62(68.1)$ \\
\hline Reduced HDL-C & $9(14.8)$ & 23 (37.7) & $1(5.9)$ & $13(76.5)$ & $11(84.6)$ & 12 (92.3) & $21(23.1)$ & $48(52.7)$ \\
\hline HTN & $6(9.8)$ & $12(19.7)$ & $5(29.4)$ & $11(64.7)$ & $12(92.3)$ & $12(92.3)$ & $23(25.3)$ & 35 (38.5) \\
\hline Elevated FG & $2(3.3)$ & $6(9.8)$ & $4(23.5)$ & $13(76.5)$ & 9 (69.2) & 9 (69.2) & $15(16.5)$ & $28(30.8)$ \\
\hline $\begin{array}{l}\text { (A): Patients without } \\
\text { (B): Patients with po } \\
\text { (C): Patients with pr } \\
\text { * Statistical significar }\end{array}$ & $\begin{array}{l}\text { ost HSCT } \\
\text { HSCT MS } \\
\text { existing MS } \\
\text { e between }\end{array}$ & Ouns fo & 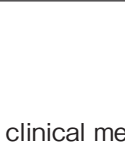 & 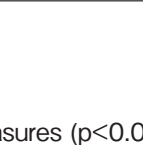 & & & & \\
\hline
\end{tabular}

Table 5. Univariate and multivariate analysis for risk factors predictive of bone loss $(\mathrm{N}=31)$

\begin{tabular}{lcccc}
\hline \multirow{2}{*}{ Variables } & \multicolumn{2}{c}{ Univariate Analysis } & \multicolumn{2}{c}{$\begin{array}{c}\text { Multivariate Analysis } \\
\text { (Adjusted for pre-existing } \\
\text { osteopenia) }\end{array}$} \\
\cline { 2 - 5 } & OR $(95 \% \mathrm{Cl})$ & $p$-value & OR $(95 \% \mathrm{Cl})$ & $p$-value \\
\hline Female & $17.3(1.4-210.1)$ & 0.028 & $50(1.9-1,000)$ & 0.02 \\
Baseline BMI & NA & 0.038 & $1.9(1.0-3.6)$ & 0.06 \\
\hline BMI, body mass index & & & &
\end{tabular}

variate and multivariate analyses are summarized in Table 5. The univariate analysis identified female sex (OR, 17.3; 95\% CI, 1.4-210.1) and baseline BMI ( $\mathrm{p}=$ 0.038 ) as risk factors for bone loss. The median baseline BMI for patients who developed bone loss was 21.3 (range, 16.2-26.7) $\mathrm{kg} / \mathrm{m}^{2}$, while that for patients who did not develop bone loss was 24.3 (range, 21.3$34.2) \mathrm{kg} / \mathrm{m}^{2}$. Female sex remained significant in the multivariate analysis after adjusting for preexisting osteopenia (OR, 50; 95\% CI, 1.9-1,000). Other factors such as calcineurin inhibitor use, corticosteroid use, time to immunosuppressant tapering, and GVHD status were not significantly different between the two groups. Risk factors for fractures have not been studied because of the low incidence rate.

\section{Sufficiency of current screening measures}

Among the 174 patients who met the study's inclu- sion criteria, 79 did not have both MS- and bone lossrelated data. Another 95 patients did not have MS- or bone loss-related data. This resulted in a total of 83 patients $(47.7 \%)$ without MS-related data and 143 patients $(82.2 \%)$ without bone-related data. All patients who were not included due to incomplete MS-related data did not have lipid panel results. Similarly, none of the patients excluded from the skeletal event analysis had BMD measurements.

In the CV study population, none of the patients had their waist circumference measured. However, all of the patients included had their height and weight monitored. An average of 2.8 lipid panels per patient were performed, at a median follow-up of 3.6 (range, 0.5341.3) years. All included patients had sufficient blood pressure and glucose monitoring. In the skeletal study population, an average of 0.38 BMD studies were performed per patient. 


\section{Discussion}

The incidence of MS in this study was $18.7 \%$, similar to that reported in other studies, as summarized in Table A2 (Appendix), ranging from 17-48\% $\%^{11,12}$. The study by Oudin et al. ${ }^{12}$ reported a low incidence of $17 \%$, likely due to the inclusion of both autologous HSCT and alloHSCT survivors. The median time to diagnosis of MS in this study was 356 (range, 44-1,792) days, with a median follow-up of 3.6 (range, 0.53-41.3) years. This was similarly reported in an earlier study where MS occurred as early as 1 year after alloHSCT ${ }^{11}$, although other studies reported the occurrence of MS at a median of 4-15 years after alloHSCT ${ }^{8,931}$. The prevalence of MS in this study was 33\%, which is in concordance with previous studies. For adolescent survivors, the prevalence of MS varied from 7-32\% ${ }^{10,14,32-35}$ at a median of 4-15 years after HSCT. In adults, it ranged from $29-49 \%$ at a median of 3-9 years after HSCT among mixed cohorts of adult autologous and allogeneic HSCT survivors $^{8,9,31}$. The prevalence of MS in this study was also higher than that of the general population of Singapore, which was reported to range from 20.0-26.9\% depending on the criteria used to define $\mathrm{MS}^{36}$.

Baseline abdominal obesity, elevated TG level, and fasting hyperglycemia were significant in the multivariate analysis adjusted for preexisting MS. This is an important finding as it underscores the importance of controlling risk factors before transplantation to optimize outcomes after alloHSCT.

Although the use of corticosteroids and calcineurin inhibitors as part of GVHD prophylaxis and treatment is known to cause metabolic derangements, such as hyperglycemia and HTN and has been previously reported to increase the risk of $\mathrm{MS}^{10}$, such findings were not reproduced in this study. This could potentially be due to differences in genetic disposition and ethnicity among the different study populations. Total time on systemic steroids, time to immunosuppressant tapering, and diagnosis of GVHD were not significantly different between the groups, according to MS status, similar to findings by other groups ${ }^{9,11}$.

Earlier studies have suggested that the use of TBI may contribute to the premature development of MS components $^{11,12,37}$. In this study, however, TBI was not shown to be a significant risk factor for MS. This could be related to the relatively lower percentage of patients treated with TBI in this study (31.6\% vs. $48-73 \%)$.

Regardless of MS status, all clinical measures of MS were significantly higher after HSCT than at baseline. Similar results were reported in earlier studies, which showed that alloHSCT increased the risk of developing abdominal obesity, dyslipidemia, HTN, and diabetes ${ }^{10,30,38-41}$.
Dyslipidemia was noted to be the most common clinical measure of MS in patients after HSCT. The incidences of reduced HDL-C and elevated TG levels were $78.7 \%$ and $68.1 \%$, respectively. Elevated TG levels were also commonly identified in other studies that included mostly older adults ${ }^{8,9,11,31}$. Another study that included young adults revealed a low HDL level to be the most common component $t^{10}$. This finding emphasizes the importance of routine monitoring of lipid panels in this patient population, given that dyslipidemia is common following $\mathrm{HSCT}^{8,9,11,31}$.

Waist measurements were not available for all patients, and BMI was used as a substitute. The use of BMI as a clinical measure of MS in this patient population may not be ideal, considering that many studies report the observation of normal BMI despite the prevalence of other metabolic disturbances ${ }^{42,43}$. This was attributed to the development of significantly altered body composition in posttransplant patients, where sarcopenic obesity resulted in an increase in the total percentage of fat mass and a decrease in lean body mass. These patients may develop insulin resistance due to the loss of myocyte insulin receptors and an increase in adipocyte insulin receptors, which are less efficient in binding insulin and clearing glucose ${ }^{43}$.

The incidences of osteopenia and osteoporosis were determined to be $38.7 \%$ and $35.5 \%$, respectively, in this study, comparable to those reported in similar studies that revealed osteopenia rates between $42 \%$ and $50 \%$ and osteoporosis rates between $25 \%$ and $32 \%^{13,19,21-23}$. However, the rate of osteoporosis in this study was higher than that reported in the general population of Singapore. In a study conducted in community-dwelling adults in Singapore, the prevalence of osteoporosis was reported to be $9.3 \%$ and $0.7 \%$ in women and men, respectively. On the other hand, the rate of osteopenia was similar to that in this study. The prevalence was reported to be $23.1 \%$ and $48.8 \%$ in women and men, respectively ${ }^{44}$.

Female sex was identified as a risk factor for the development of bone loss after alloHSCT from the multivariate analysis after adjusting for preexisting osteopenia. This was also observed in previous studies ${ }^{13}$. Female sex is also a common risk factor for bone loss in the general population ${ }^{45}$, and the HSCT process could potentially exacerbate the risk in this group of patients.

Prior studies have shown that the use of corticosteroids and calcineurin inhibitors may accelerate bone loss in alloHSCT recipients by decreasing bone production and increasing bone resorption ${ }^{21,46,47}$. In this study, however, this association was not identified, which is consistent with the findings of three other studies ${ }^{19,48,49}$. It is postulated that mechanisms other than corticosteroid and calcineurin inhibitor use may contribute to BMD 
loss after alloHSCT. This may be a result of direct toxicity to the bone and bone marrow stromal cells by conditioning as well as bone loss promoted by rapid changes in cytokines immediately following $\mathrm{HSCT}^{19}$.

It was found that the current recommendations were not adhered to for several important parameters. Almost half of the study population $(47.7 \%)$ did not have their lipid panels measured. According to current guideline recommendations ${ }^{13,26}$, all patients should have an initial lipid profile performed 3 months after HSCT, followed by regular intervals according to their risk category. Nonadherence was likely due to a lack of available institutional guidelines. This is an exceptionally important finding and area for improvement, as it is evident from the results that this patient population is especially susceptible to dyslipidemia after alloHSCT. Although the correlation between poorly controlled $\mathrm{CV}$ risk factors and CV events was not demonstrated in this study due to the small number of events, it is an established fact that dyslipidemia may potentially contribute to increased CV morbidity and mortality in the long run ${ }^{50,51}$.

Deficiency in bone loss screening was also found in this study, where $82.2 \%$ of the patients did not have BMD data available at a median follow-up of 4.8 years. The incidences of bone, loss, and fractures in Asia are similar or even higher than those in Western countries due to widespread calcium and vitamin D deficiency, even in the general population ${ }^{52}$. The rate of calcium and vitamin D supplementation in this study population was also low (41.9\%). Taken together, these findings underscore the importance of implementing measures to ensure routine and timely screening for bone loss and calcium/vitamin D deficiency after HSCT.

The limitations of this study include its retrospective nature, and only associations, but not causal relationships, could be determined. Furthermore, the accuracy and completeness of the data collection were largely dependent on high-quality existing data. The small sample size and heterogeneity of patients were other limitations that would warrant further studies in other independent cohorts to confirm the results of this study. The small sample size of this study also contributed to the inability to identify risk factors for $\mathrm{CV}$ events and fractures.

Due to the lack of data in many patients, selection bias could not be excluded. Patients deemed to be at higher risk of posttransplant complications might have been screened and followed up more closely. Confounding factors such as dietary patterns, alcohol intake, smoking status, and other lifestyle modifications as well as family history of CV diseases were not adequately captured in this study. We also did not examine the previous chemotherapy history of these patients, particularly the use of anthracyclines, which have been well established, to contribute to late $\mathrm{CV}$ complications.

\section{Future directions and conclusion}

Currently, there are no institutional guidelines recommending the initial and subsequent screening time points. This study outlines the importance of developing institutional guidelines and implementation methods to improve long-term outcomes. This could be performed by implementing a screening chart for physicians to follow up on tests that are required at each time point or setting up a long-term follow-up clinic, where specialized physicians and healthcare professionals work together to monitor these survivors to ensure optimal long-term outcomes.

In conclusion, this study showed that suboptimal control of $\mathrm{CV}$ risk factors at baseline may potentially increase the risk of developing MS after alloHSCT. Females are also at an increased risk of developing bone loss after alloHSCT. This highlights the importance of screening for all clinical measures of MS and identifying patients at risk of bone loss prior to transplantation, as well as frequent monitoring in these patients after HSCT. Strategies to ensure timely and adequate monitoring and preventive measures are crucial.

However, with the limitations of a short study duration and small number of events, the risk factors for CV events and fractures could not be fully elucidated. More studies with longer follow-up periods are needed to fully understand the long-term implications of MS and bone loss in patients after alloHSCT.

\section{Author Contributions}

M.F. Chong designed the study, collected and analyzed data, and wrote the manuscript.

Y.J. Lim and H.Y. $\mathrm{Ng}$ provided guidance on the above.

\section{Conflicts of Interest}

The authors declare no conflict of interest. Disclosure forms provided by the authors are available on the website.

\section{References}

1. Brennan BM, Shalet SM. Endocrine late effects after bone marrow transplant. Br J Haematol. 2002; 118: 58-66.

2. Leiper AD. Non-endocrine late complications of bone marrow transplantation in childhood: part II. Br J Haematol. 2002; 118: $23-43$.

3. Leiper AD. Non-endocrine late complications of bone marrow transplantation in childhood: part I. Br J Haematol. 2002; 
118: $3-22$.

4. Socie G, Salooja N, Cohen A, Rovelli A, Carreras E, Locasciulli A, et al. Nonmalignant late effects after allogeneic stem cell transplantation. Blood. 2003; 101: 3373-85.

5. Bhatia S, Robison LL, Francisco L, Carter A, Liu Y, Grant $\mathrm{M}$, et al. Late mortality in survivors of autologous hematopoietic-cell transplantation: report from the Bone Marrow Transplant Survivor Study. Blood. 2005; 105: 4215-22.

6. Bhatia S, Francisco L, Carter A, Sun CL, Baker KS, Gurney JG, et al. Late mortality after allogeneic hematopoietic cell transplantation and functional status of long-term survivors: report from the Bone Marrow Transplant Survivor Study. Blood. 2007; 110: 3784-92.

7. Martin PJ, Counts GW, Jr., Appelbaum FR, Lee SJ, Sanders JE, Deeg HJ, et al. Life expectancy in patients surviving more than 5 years after hematopoietic cell transplantation. J Clin Oncol. 2010; 28: 1011-6.

8. Annaloro C, Usardi P, Airaghi L, Giunta V, Forti S, Orsatti A, et al. Prevalence of metabolic syndrome in long-term survivors of hematopoietic stem cell transplantation. Bone Marrow Transplant. 2008; 41: 797-804.

9. Majhail NS, Flowers ME, Ness KK, Jagasia M, Carpenter PA, Arora M, et al. High prevalence of metabolic syndrome after allogeneic hematopoietic cell transplantation. Bone Marrow Transplant. 2009; 43: 49-54.

10. Paris C, Yates L, Lama P, Zepeda AJ, Gutierrez D, Palma J. Evaluation of metabolic syndrome after hematopoietic stem cell transplantation in children and adolescents. Pediatr Blood Cancer. 2012; 59: 306-10.

11. McMillen KK, Schmidt EM, Storer BE, Bar M. Metabolic syndrome appears early after hematopoietic cell transplantation. Metab Syndr Relat Disord. 2014; 12: 367-71.

12. Oudin C, Auquier P, Bertrand Y, Contet A, Kanold J, Sirvent $\mathrm{N}$, et al. Metabolic syndrome in adults who received hematopoietic stem cell transplantation for acute childhood leukemia: an LEA study. Bone Marrow Transplant. 2015; 50: 1438-44.

13. Majhail NS, Rizzo JD, Lee SJ, Aljurf M, Atsuta Y, Bonfim C, et al. Recommended screening and preventive practices for long-term survivors after hematopoietic cell transplantation. Biol Blood Marrow Transplant. 2012; 18: 348-71.

14. Taskinen M, Saarinen-Pihkala UM, Hovi L, Lipsanen-Nyman M. Impaired glucose tolerance and dyslipidaemia as late effects after bone-marrow transplantation in childhood. Lancet. 2000; 356: 993-7.

15. Grundy SM, Cleeman JI, Daniels SR, Donato KA, Eckel RH, Franklin BA, et al. Diagnosis and management of the metabolic syndrome: an American Heart Association/National Heart, Lung, and Blood Institute Scientific Statement. Circulation. 2005; 112: 2735-52.

16. Trigg ME, Finlay JL, Bozdech M, Gilbert E. Fatal cardiac toxicity in bone marrow transplant patients receiving cytosine arabinoside, cyclophosphamide, and total body irradiation. Cancer. 1987; 59: 38-42.

17. Uderzo C, Pillon M, Corti P, Tridello G, Tana F, Zintl F, et al. Impact of cumulative anthracycline dose, preparative regimen and chronic graft-versus-host disease on pulmonary and cardiac function in children 5 years after allogeneic hematopoietic stem cell transplantation: a prospective evaluation on behalf of the EBMT Pediatric Diseases and Late Effects Working Parties. Bone Marrow Transplant. 2007; 39: 667-75.
18. Tichelli A, Rovo A, Gratwohl A. Late pulmonary, cardiovascular, and renal complications after hematopoietic stem cell transplantation and recommended screening practices. Hematology Am Soc Hematol Educ Program. 2008; 1: 125-33.

19. Yao S, McCarthy PL, Dunford LM, Roy DM, Brown K, Paplham P, et al. High prevalence of early-onset osteopenia/ osteoporosis after allogeneic stem cell transplantation and improvement after bisphosphonate therapy. Bone Marrow Transplant. 2008; 41: 393-8.

20. Lewiecki EM, Laster AJ. Clinical review: Clinical applications of vertebral fracture assessment by dual-energy $\mathrm{x}$-ray absorptiometry. J Clin Endocrinol Metab. 2006; 91: 4215-22.

21. Schulte CM, Beelen DW. Bone loss following hematopoietic stem cell transplantation: a long-term follow-up. Blood. 2004; 103: 3635-43.

22. Savani BN, Donohue T, Kozanas E, Shenoy A, Singh AK, Childs RW, et al. Increased risk of bone loss without fracture risk in long-term survivors after allogeneic stem cell transplantation. Biol Blood Marrow Transplant. 2007; 13: 517-20.

23. McClune BL, Polgreen LE, Burmeister LA, Blaes AH, Mulrooney DA, Burns LJ, et al. Screening, prevention and management of osteoporosis and bone loss in adult and pediatric hematopoietic cell transplant recipients. Bone Marrow Transplant. 2011; 46: 1-9.

24. Buckley L, Greenwald RM, Hochberg M, Lane N, Lindsey S, Paget S, et al. Recommendations for the prevention and treatment of glucocorticoid-induced osteoporosis: 2001 update. American College of Rheumatology Ad Hoc Committee on Glucocorticoid-Induced Osteoporosis. Arthritis Rheum. 2001; 44: $1496-503$

25. Rizzo JD, Wingard JR, Tichelli A, Lee SJ, Van Lint MT, Burns LJ, et al. Recommended screening and preventive practices for long-term survivors after hematopoietic cell transplantation: joint recommendations of the European Group for Blood and Marrow Transplantation, the Center for International Blood and Marrow Transplant Research, and the American Society of Blood and Marrow Transplantation. Biol Blood Marrow Transplant. 2006; 12: 138-51.

26. DeFilipp Z, Duarte RF, Snowden JA, Majhail NS, Greenfield DM, Miranda JL, et al. Metabolic syndrome and cardiovascular disease following hematopoietic cell transplantation: screening and preventive practice recommendations from CIBMTR and EBMT. Bone Marrow Transplant. 2017; 52: 173-82.

27. Alberti KG, Eckel RH, Grundy SM, Zimmet PZ, Cleeman JI, Donato KA, et al. Harmonizing the metabolic syndrome: a joint interim statement of the International Diabetes Federation Task Force on Epidemiology and Prevention; National Heart, Lung, and Blood Institute; American Heart Association; World Heart Federation; International Atherosclerosis Society; and International Association for the Study of Obesity. Circulation. 2009; 120: 1640-5.

28. WHO. Appropriate body-mass index for Asian populations and its implications for policy and intervention strategies. Lancet. 2004; 363: 157-63.

29. Kanis JA, Gluer CC. An update on the diagnosis and assessment of osteoporosis with densitometry. Committee of Scientific Advisors, International Osteoporosis Foundation. Osteoporos Int. 2000; 11: 192-202.

30. Tichelli A, Bucher C, Rovo A, Stussi G, Stern M, Paulussen $\mathrm{M}$, et al. Premature cardiovascular disease after allogeneic he- 
matopoietic stem-cell transplantation. Blood. 2007; 110: 3463-71.

31. Higgins K, Noon C, Davies M, Howlett T, Hunter A. Features of the metabolic syndrome present in survivors of bone marrow transplantation in adulthood. Bone Marrow Transplant. 2005; 36: 279-80; author reply 80 .

32. Taskinen M, Lipsanen-Nyman M, Tiitinen A, Hovi L, Saarinen-Pihkala UM. Insufficient growth hormone secretion is associated with metabolic syndrome after allogeneic stem cell transplantation in childhood. J Pediatr Hematol Oncol. 2007; 29: 529-34.

33. Oudin C, Simeoni MC, Sirvent N, Contet A, Begu-Le Coroller A, Bordigoni $\mathrm{P}$, et al. Prevalence and risk factors of the metabolic syndrome in adult survivors of childhood leukemia. Blood. 2011; 117: 4442-8.

34. Bajwa R, Skeens M, Garee A, Miao Y, Soni S, Pietryga D, et al. Metabolic syndrome and endocrine dysfunctions after HSCT in children. Pediatr Transplant. 2012; 16: 872-8.

35. Frisk P, Arvidson J, Larsson M, Naessen T. Risk factors for cardiovascular disease are increased in young adults treated with stem cell transplantation during childhood. Pediatr Transplant. 2012; 16: 385-91.

36. Ranasinghe P, Mathangasinghe Y, Jayawardena R, Hills AP, Misra A. Prevalence and trends of metabolic syndrome among adults in the asia-pacific region: a systematic review. BMC Public Health. 2017; 17: 101.

37. Armenian SH, Sun CL, Vase T, Ness KK, Blum E, Francisco $\mathrm{L}$, et al. Cardiovascular risk factors in hematopoietic cell transplantation survivors: role in development of subsequent cardiovascular disease. Blood. 2012; 120: 4505-12.

38. Kyle UG, Chalandon Y, Miralbell R, Karsegard VL, Hans D, Trombetti A, et al. Longitudinal follow-up of body composition in hematopoietic stem cell transplant patients. Bone Marrow Transplant. 2005; 35: 1171-7.

39. Baker KS, Ness KK, Steinberger J, Carter A, Francisco L, Burns LJ, et al. Diabetes, hypertension, and cardiovascular events in survivors of hematopoietic cell transplantation: a report from the bone marrow transplantation survivor study. Blood. 2007; 109: 1765-72.

40. Kagoya Y, Seo S, Nannya Y, Kurokawa M. Hyperlipidemia after allogeneic stem cell transplantation: prevalence, risk factors, and impact on prognosis. Clin Transplant. 2012; 26: E 168-75.

41. Pophali PA, Klotz JK, Ito S, Jain NA, Koklanaris E, Le RQ, et al. Male survivors of allogeneic hematopoietic stem cell transplantation have a long term persisting risk of cardiovascular events. Exp Hematol. 2014; 42: 83-9.

42. Mosesso K. Adverse Late and Long-Term Treatment Effects in Adult Allogeneic Hematopoietic Stem Cell Transplant Survivors. The American journal of nursing. 2015; 115: 22-34; quiz 5.

43. Baker KS, Chow E, Steinberger J. Metabolic syndrome and cardiovascular risk in survivors after hematopoietic cell transplantation. Bone Marrow Transplant. 2012; 47: 619-25.

44. Chen KK, Wee SL, Pang BWJ, Lau LK, Jabbar KA, Seah WT, et al. Bone mineral density reference values in Singaporean adults and comparisons for osteoporosis establishment The Yishun Study. BMC Musculoskelet Disord. 2020; 21: 633.

45. Cosman F, de Beur SJ, LeBoff MS, Lewiecki EM, Tanner B, Randall S, et al. Clinician's Guide to Prevention and Treatment of Osteoporosis. Osteoporos Int. 2014; 25: 2359-81.

46. Ebeling PR, Thomas DM, Erbas B, Hopper JL, Szer J, Grigg AP. Mechanisms of bone loss following allogeneic and autologous hemopoietic stem cell transplantation. J Bone Miner Res. 1999; 14: 342-50.

47. Stern JM, Sullivan KM, Ott SM, Seidel K, Fink JC, Longton $\mathrm{G}$, et al. Bone density loss after allogeneic hematopoietic stem cell transplantation: a prospective study. Biol Blood Marrow Transplant. 2001; 7: 257-64.

48. Bhatia S, Ramsay NK, Weisdorf D, Griffiths H, Robison LL. Bone mineral density in patients undergoing bone marrow transplantation for myeloid malignancies. Bone Marrow Transplant. 1998; 22: 87-90.

49. Kauppila M, Irjala K, Koskinen P, Pulkki K, Sonninen P, Viikari J, et al. Bone mineral density after allogeneic bone marrow transplantation. Bone Marrow Transplant. 1999; 24: 8859.

50. Lloyd-Jones DM, Leip EP, Larson MG, D'Agostino RB, Beiser A, Wilson PW, et al. Prediction of lifetime risk for cardiovascular disease by risk factor burden at 50 years of age. Circulation. 2006; 113: 791-8.

51. Chow EJ, Wong K, Lee SJ, Cushing-Haugen KL, Flowers ME, Friedman DL, et al. Late cardiovascular complications after hematopoietic cell transplantation. Biol Blood Marrow Transplant. 2014; 20: 794-800.

52. IOF. The Asian Audit: Epidemiology, costs and burden of osteoporosis in Asia 2009. https://www.iofbonehealth.org/sites/ default/files/PDFs/Audit Asia/Asian_regional_audit_2009. pdf\%5D [Accessed: 2 July 2018]

53. Turcotte LM, Yingst A, Verneris MR. Metabolic Syndrome after Hematopoietic Cell Transplantation: At the Intersection of Treatment Toxicity and Immune Dysfunction. Biol Blood Marrow Transplant. 2016; 22: 1159-66.

https://doi.org/10.31547/bct-2020-020

Copyright (C)2021 Asia-Pacific Blood and Marrow Transplantation Group (APBMT). This is an open access article distributed under CC BY-NC license (https://creativecommon s.org/licenses/by-nc/4.0/). 